\title{
LATE QUATERNARY HISTORY OF CONTINENTAL CLIMATE AND THE BENGUELA CURRENT OFF SOUTH WEST AFRICA
}

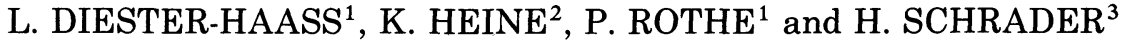 \\ ${ }^{1}$ Geographisches Institut der Universität, Abteilung für Geologie, Postfach 103462, D-6800 Mannheim (F.R.G.) \\ ${ }^{2}$ Geographisches Institut der Universität, Universitätsstr. 31, D-8400 Regensburg (F.R.G.) \\ ${ }^{3}$ College of Oceanography, Oregon State University, Corvallis, OR 97331 (U.S.A.) and Geological Institute Avd. B., \\ University of Bergen, $\mathrm{N}-5000$ Bergen (Norway)
}

(Received February 17, 1987; revised and accepted September 7, 1987)

\begin{abstract}
Diester-Haass, L., Heine, K., Rothe, P. and Schrader, H., 1988. Late Quaternary history of continental climate and the Benguela Current off South West Africa. Palaeogeogr., Palaeoclimatol., Palaeoecol., 65: 81-91.

Late Quaternary sediments from the southwest African continental slope were analyzed for their coarse fraction, diatom and clay mineral content and composition. Changes in the flow pattern of the Benguela Current were inferred from the abundance and preservation of opaline microfossils and diatom species composition. The Benguela Current turned westward in the general latitude of $24^{\circ} \mathrm{S}$ during oxygen isotope stages 1 and 3 ; this flow pattern caused transportation of opaline microorganisms from the near shore area to the continental slope area or caused increased upwelling phenomena further offshore. During oxygen isotope stage 2, on the other hand, the westward deflection of the Benguela Current was moved further to the north.

Two sources of terrigenous material were determined: one is local with supply from the Namib desert, the other one is distant with supply from the Orange River mouth; material from the Orange River mouth might have been transported to the north by the Benguela Current. The local terrigenous supply from the Namib desert increased during oxygen isotope stage 2 as evidenced by the increased amounts of terrigenous matter, by an increase of illite and by greater grain sizes.

Occurrence of wood fibres in oxygen isotope stage 3 indicates a denser continental vegetation over the present Namib desert.
\end{abstract}

\section{Introduction}

Paleoclimatic changes in arid continental areas are difficult to detect because of poor preservation of climate proxies and correct age determinations. Marine sediments deposited off arid areas may contain information on climate changes of the neighbouring continents. We present results from a core taken from the continental slope off southwest Africa with the aim to provide information about paleoclimatic changes that occurred over the last $30,000-35,000$ years.

\section{Material and methods}

Core PC 16 was retrieved from $2199 \mathrm{~m}$ water depth off Concepcion Bay at $24^{\circ} 04^{\prime} 17^{\prime \prime} \mathrm{S}$, $12^{\circ} 39^{\prime} 93^{\prime \prime} \mathrm{E}$ during Chain Cruise 115 (Summerhayes et al., 1979) (Fig.1). No signs of slumping or chaotic bedding are visible over the entire core length of $813 \mathrm{~cm}$. The $3.5 \mathrm{kHz}$ echosounding profiles show well-laminated reflectors (op. cit.). Down core water content is more or less constant; the sediments are calcareous clays at the bottom of the core, grading into calcareous/siliceous ooze and into calcareous 


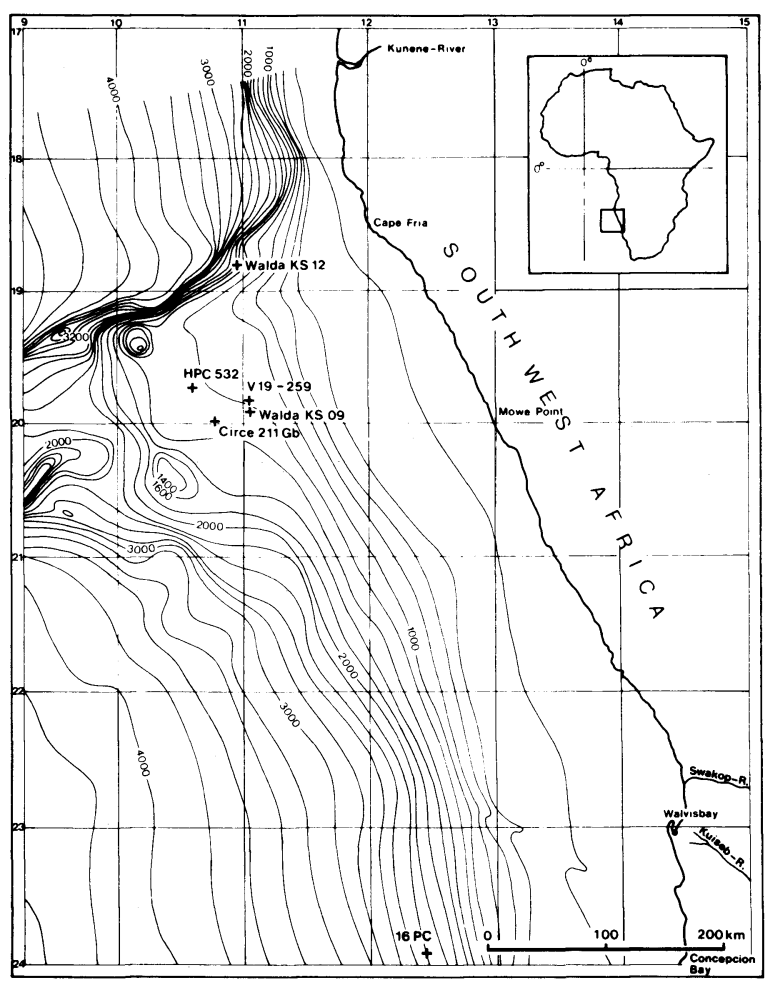

Fig.1. Position of Chain 115 core PC 16 and of cores from the Walvis Ridge, cited in the text.

ooze toward the top. A marked color change occurs at $140 \mathrm{~cm}$ with a light gray color above and an olive green color below the boundary. We assume that the section represents undisturbed autochthonous sedimentation based on lithologic evidence.

The coarse fraction analysis was done by Diester-Haass, Schrader did the diatom analysis and Rothe did the clay mineral analysis of all 20 -cm evenly spaced samples taken over the entire length of the core. Heine contributed the paleoclimatic information from the SW African deserts.

Coarse fraction analysis (Sarnthein, 1971)

Samples were dried, weighed and wet sieved through a 40 and a $63 \mu \mathrm{m}$ sieve. The residue was dried, weighed and the $>63 \mu \mathrm{m}$ fraction sieved into the following subfractions: $63-125$, $125-250,250-500, \quad 500-1000$ and $>1000 \mu \mathrm{m}$; each subfraction was weighed and about 800 grains were counted and identified (biogenous, terrigenous and authigenous). The percent composition of the sand $(>63 \mu \mathrm{m})$ and the coarse silt $(40-63 \mu \mathrm{m})$ fraction was calculated by combining the percent composition (grain numbers) and weight percent of the individual fractions. The $\mathrm{CaCO}_{3}$ content was determined by the carbonate bomb method (Müller and Gastner, 1971). $\mathrm{C}_{\text {org }}$ values were provided by Summerhayes.

\section{Diatom analysis}

Samples were prepared according to the methods outlined in Schrader and Gersonde (1978).

\section{Clay mineralogy}

Clay minerals were determined by X-ray diffraction as described in Diester-Haass et al. (1986).

\section{Physiographic setting}

Core PC 16 was collected from the South West African continental slope (Fig.1); the climate in this area is generally arid with only $13 \mathrm{~mm}$ annual rainfall (Bremner, 1975); no continuously flowing rivers are present in the area. The South East trade wind is the prevailing wind; the SE-NW flowing Benguela Current parallels the trade wind system (Darbyshire, 1966). The Benguela Current shifts from a primarily SE-NW direction to a WNW and W direction around $24-20^{\circ} \mathrm{S}$ latitude (Hart and Currie, 1960; Martin, 1981; Simpson, 1971). Coastal upwelling is caused by the trade winds and occurs along the inner shelf and on the shelf edge (Summerhayes, 1983; Schuette and Schrader, 1981). Eddies of upwelled water are drifted seaward by the Benguela Current and opal skeletons from the upwelling centers may be transported seaward (Hagen et al., 1981).

\section{Results}

The coarse fraction component decreases sharply from $10-20 \%$ in the upper $200 \mathrm{~cm}$ to $<5 \%$ below (Fig.2a). The sand fraction consists of radiolaria, benthic and planktonic 
foraminifera (Fig.2b). The abundance of planktonic foraminifera decreases and the fragmentation of these increases below $160 \mathrm{~cm}$ indicating an increase of carbonate dissolution (Thunell, 1976). The benthos/plankton foraminiferal ratios increase as does fragmentation.
Fragmentation and the benthos/plankton foraminiferal ratios decrease between $500-600 \mathrm{~cm}$ downcore (Fig.2c, d). Globorotalia menardii is present in the uppermost $60 \mathrm{~cm}$.

The radiolarian/benthic foraminiferal ratio shows maxima at the upper $120 \mathrm{~cm}$, at $280 \mathrm{~cm}$

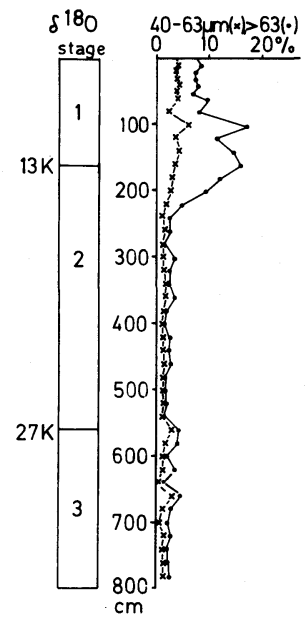

a

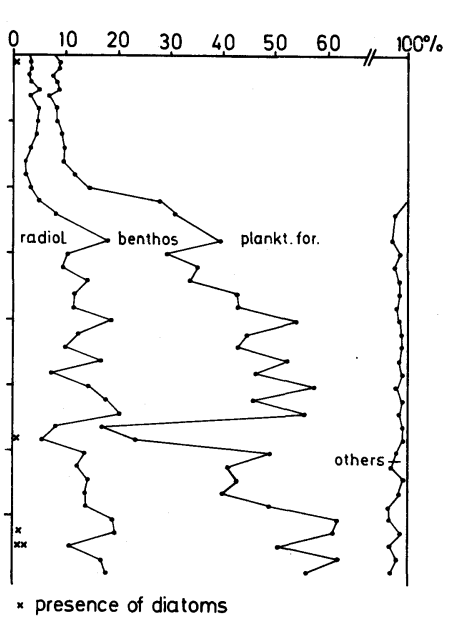

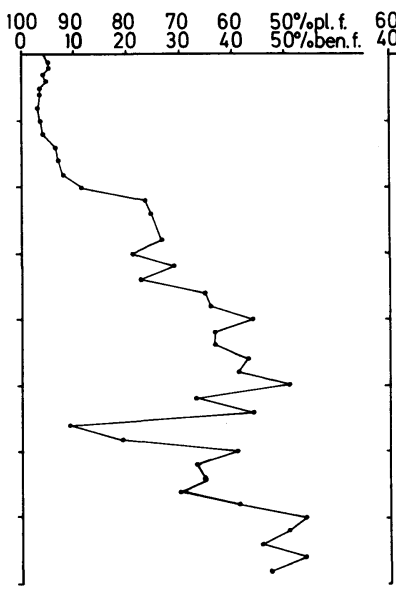

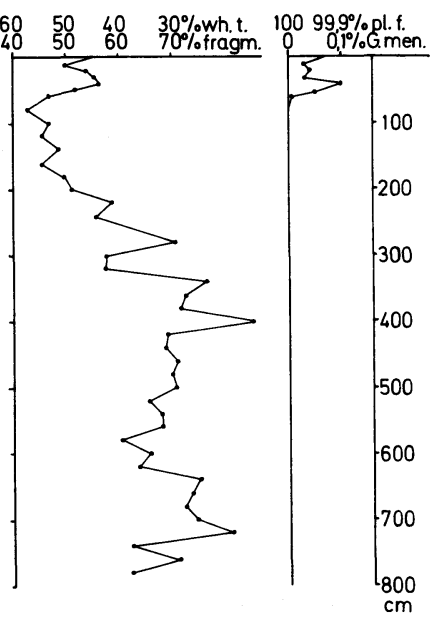

d

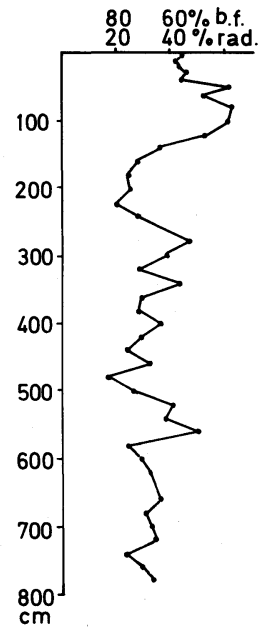

e

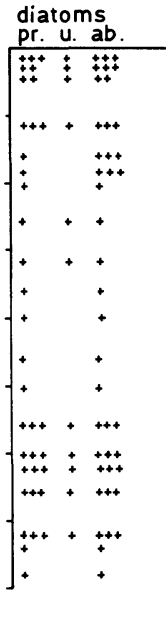

f

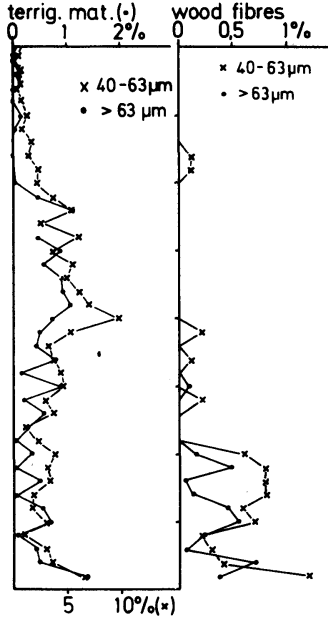

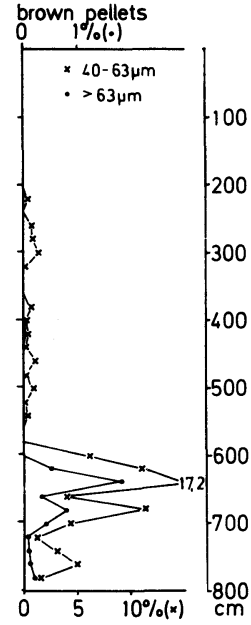

h

Fig.2. Results of PC 16. Left side: stratigraphy (for method see text). a. Percentage of sand- and coarse silt (40-63 $\mu$ m) fraction. b. Composition of the sand fraction. c. Benthos/plankton foraminiferal ratio, calculated as (benthonic foraminifera/benthonic + planktonic foraminifera) $\times 100$. d. Fragmentation of planktonic foraminifera, calculated as (fragments/fragments + whole tests) $\times 100$. Ratio of Globorotalia menardii (G. men.) versus percentage of planktonic foraminifera, calculated as (G. menardii/G. menardii + planktonic foraminifera) $\times 100$. e. Ratio of radiolaria versus benthonic foraminifera, calculated as (radiolaria/radiolaria + benthonic foraminifera) $\times 100$. f. Diatom preservation ( $p r$.) and abundance $(a b$.$) . U=$ diatoms indicate upwelling influence. Preservation: $+=$ poor; $++=$ moderate; $+++=$ good. Abundance: $+=$ few; $++=$ common; $+++=$ abundant. g. Percentage of terrigenous matter in the sand- and $40-63 \mu \mathrm{m}$ fraction. h. Percentage of wood fibres and brown pellets with wood fibres in the sand- and $40-63 \mu \mathrm{m}$ fraction. i. Montmorillonite/illite ratio. j. Grain size distribution of acid insoluble material. k. $\mathrm{CaCO}_{3}$ and organic carbon content. 

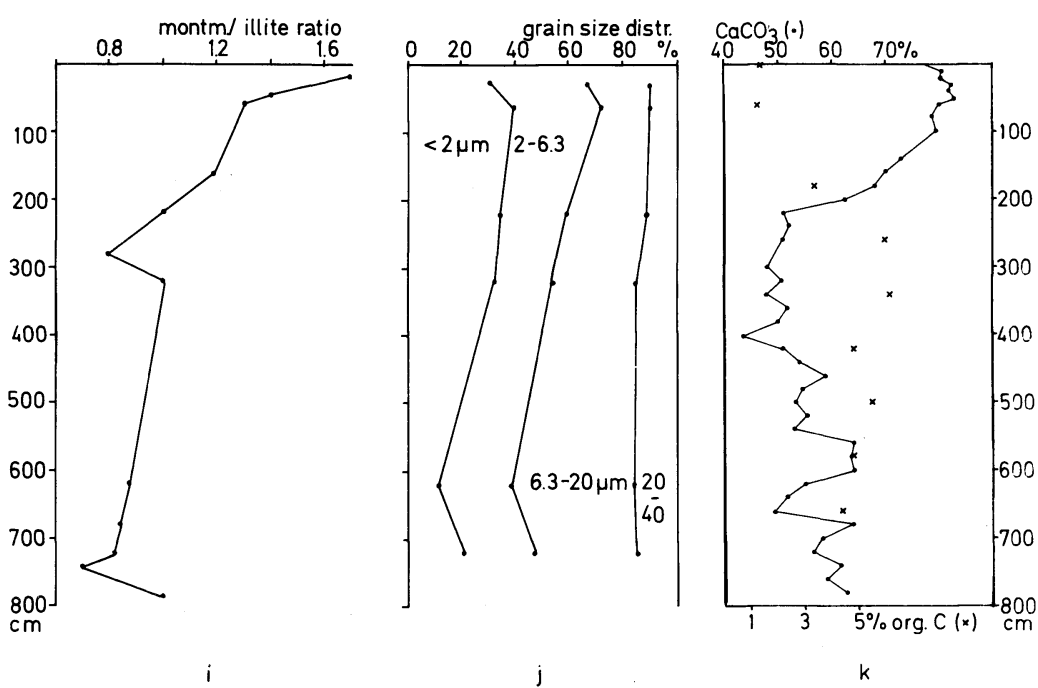

Fig.2. (continued).

and at $500-600 \mathrm{~cm}$ and minima in the 160 $260 \mathrm{~cm}$ interval. Radiolarian percentages are controlled by varying planktonic foraminiferal percentages and carbonate dissolution. Benthic foraminifera are three times less dissolved than planktonic ones (Arrhenius, 1952); thus the ratio of radiolaria versus benthonic foraminifera is a measure of opal preservation and supply. The higher the opal production, the better the opal preservation and the more abundant are opal skeletons in the sediments relative to benthonic foraminifera.

Diatom abundance and preservation are plotted on Fig.2f; two maxima are obvious: in the top $120 \mathrm{~cm}$ and in the $560-720 \mathrm{~cm}$ range. The monospecific Coscinodiscus nodulifer interval between $120-200 \mathrm{~cm}$ co-occurs with the carbonate preservation spike.

Terrigenous matter abundances in the coarse fraction are small, they show an increase between $200-400 \mathrm{~cm}$ and a minimum in the upper $120 \mathrm{~cm}$ (Fig.2g) and consist of quartz and mica.

Wood fibres and brown pellets, made up of a mixture of clay and wood fibres, occur in the lower section of the core with a maximum at 580-800 cm (Fig.2h).

Clay minerals were analyzed in several samples (Table II); kaolinite percentages vary between 9 and 19\% and show little variation over the entire length of the core. There is an increase in illite compared to montmorillonite with depth in core (Fig.2i).

The grain size distribution of the insoluble fraction (Fig.2j) shows a coarsening with depth: the amount of the $<2 \mu \mathrm{m}$ fraction decreases whereas the $6.3-20 \mu \mathrm{m}$ fraction increases.

The carbonate content (Fig. $2 \mathrm{k}$ ) is $65-80 \%$ in the upper $160 \mathrm{~cm}$ and decreases to $45-65 \%$ in the lower part; it varies similarly to the benthos/planktonic foraminiferal ratios. Organic matter values exhibit the opposite trend with $1 \%$ in the upper part and maxima of $6 \%$ in the $250-350 \mathrm{~cm}$ core interval.

The stratigraphic framework (Fig.2, left side) was established by lithostratigraphic correlation and by the presence of Globorotalia menardii in the upper $60 \mathrm{~cm}$ after the carbonate dissolution maximum (Sarnthein et al., 1982) described the same stratigraphic position of the first appearance of G. menardii). The carbonate dissolution curve of core PC 16 is very similar to the carbonate dissolution curve at DSDP-IPOD Site 532 from the Walvis Ridge Terrace (see Fig.1 for location of Site 532). An oxygen isotope curve is available from Site 532 (Diester-Haass, 1985) and was used for strati- 


\section{TABLE I}

Diatom analysis core PC 16

\begin{tabular}{|c|c|c|c|}
\hline $\begin{array}{l}\text { Sample } \\
\text { (cm) }\end{array}$ & Abundance & Preservation & Remarks (floral composition, species, etc) \\
\hline $17-19$ & common & good & P. doliolus, T. oestrupii, T. lineata, C. nodulifer, radiolaria fragmented \\
\hline $27-29$ & common & moderate & similar to above \\
\hline $47-49$ & common & moderate & similar to above \\
\hline $118-120$ & common & good & D. epiodon, Delphineis, Chaetoceros, more "upwelling" than above \\
\hline $158-160$ & common & poor & monospecific Coscinodiscus nodulifer \\
\hline $178-180$ & common & poor & monospecific Coscinodiscus nodulifer \\
\hline $198-200$ & few & poor & monospecific Coscinodiscus nodulifer, few radiolaria \\
\hline $258-260$ & few & moderate & Chaetoceros, Delphineis, "upwelling", colder water \\
\hline $318-320$ & few & moderate & very similar to above $258-260 \mathrm{~cm}$ sample \\
\hline $358-360$ & few & poor & Coscinodiscus nodulifer, Ethmodiscus, few radiolaria \\
\hline $398-400$ & few & poor & few Chaetoceros, Coscinodiscus nodulifer, Ethmodiscus, similar to above \\
\hline $458-460$ & few & poor & few Chaetoceros, few radiolaria \\
\hline $498-500$ & few & poor & same as above \\
\hline $558-560$ & common & good & Chaetoceros, $P$. doliolus, Actinocyclus, "upwelling", colder waters \\
\hline $598-600$ & common & good & Chaetoceros, T. oestrupii, Actinoptychus, Actinocyclus, "upwelling" \\
\hline $618-620$ & common & good & very similar to above sample $598-560 \mathrm{~cm}$ \\
\hline $658-660$ & common & good & Chaetoceros, Actinocyclus, Actinoptychus, C. nodulifer, "upwelling" \\
\hline $718-720$ & common & good & $\begin{array}{l}\text { Chaetoceros, Actinocyclus, Actinoptychus, C. nodulifer, T. oestrupii, } \\
\text { "upwelling" }\end{array}$ \\
\hline $738-740$ & few & poor & Coscinodiscus nodulifer, warmer, less fertility \\
\hline $778-780$ & few & poor & similar to above but more Chaetoceros, warmer, less fertile, some transport \\
\hline
\end{tabular}

\section{TABLE II}

Clay mineral composition in PC 16 and in samples from the Orange River and the Namib

\begin{tabular}{|c|c|c|c|c|}
\hline $\begin{array}{l}\text { Sample } \\
(\mathrm{cm})\end{array}$ & $\begin{array}{l}\text { Kaolinite } \\
(\%)\end{array}$ & $\begin{array}{l}\text { Illite } \\
(\%)\end{array}$ & $\begin{array}{l}\text { Montmorillonite } \\
(\%)\end{array}$ & $\begin{array}{l}\text { Chlorite } \\
(\%)\end{array}$ \\
\hline $17-19$ & 9 & 34 & 57 & - \\
\hline $47-49$ & 9 & 38 & 53 & - \\
\hline $58-60$ & 11 & 38 & 51 & - \\
\hline $158-160$ & 8 & 42 & 50 & - \\
\hline $218-220$ & 19 & 40 & 41 & - \\
\hline $278-280$ & 15 & 46 & 39 & - \\
\hline $318-320$ & 16 & 43 & 41 & - \\
\hline $618-620$ & 14 & 46 & 40 & - \\
\hline $678-680$ & 7 & 50 & 43 & - \\
\hline $718-720$ & 15 & 48 & 37 & - \\
\hline $738-740$ & 7 & 54 & 39 & - \\
\hline $778-780$ & 9 & 45 & 46 & - \\
\hline $\begin{array}{l}\text { Helskloofhek, } \\
\text { Orange River, } \\
\text { ca. } 29^{\circ} \mathrm{S}\end{array}$ & - & $30-50$ & $50-70$ & - \\
\hline $\begin{array}{l}\text { Namib Desert, } \\
24^{\circ} 30^{\prime} \mathrm{S}\end{array}$ & - & $84-90$ & - & $10-16$ \\
\hline
\end{tabular}


graphic framework interpretation. This isotope curve parallels the known and well dated Quaternary carbonate preservation profiles from other parts of the Atlantic Ocean (Berger, 1977), where the last glacial carbonate dissolution spike is followed by a carbonate preservation spike close to the last glacial/Holocene boundary.

Correlation between Site 532 and PC 16 leads to the assumption that the stage $1 / 2$ boundary at core PC 16 is around $160 \mathrm{~cm}$. Based on this boundary, Holocene accumulation rates are $12 \mathrm{~cm} / 1000 \mathrm{yr}$. The stratigraphy of the lower part is based on the following two assumptions: (1) The $\mathrm{CaCO}_{3}$ content shows a significant increase at $560 \mathrm{~cm}$ simultaneous to a decrease in carbonate dissolution. The oxygen isotope $2 / 3$ boundary in the Atlantic is characterized by an increase in the $\mathrm{CaCO}_{3}$ content (Sarnthein et al., 1982; Thiede et al., 1982 (Atlantic off NW Africa); Embley and Morley, 1980 (Cape Basin); Diester-Haass, 1985 (Walvis Ridge)). (2) Accumulation rates in the Atlantic Ocean increased by a factor of 2-3 in the last glacial period compared to Holocene values (Broecker, 1971; Diester-Haass et al., 1973). Accumulation rates of $29 \mathrm{~cm} / 1000 \mathrm{yr}$ can be calculated under the assumption that the stage 2 is represented by core interval $160-560 \mathrm{~cm}$. This increase in sedimentation rate corresponds to similar ones in the glacial Atlantic.

The above assumptions form the basis to place the oxygen isotope stage $2 / 3$ boundary at $560 \mathrm{~cm}$. A decrease in sedimentation rate during stage 3 is poorly understood; we therefore cannot assign an age to the base of the core.

\section{Discussion}

\section{Upwelling and Benguela Current}

Sediments from the continental margins are poor in opal microfossils in general; they can be rich in these skeletons if the supply rate is high enough to compensate for dissolution of opal at the sediment water interface and in the sediments (Johnson, 1974; Berger, 1976). Opal microfossils (radiolaria and diatoms) are excellent indicators of increased surface water fertility which in turn controls productivity, higher opal skeleton fluxes and enhanced preservation of opaline skeletons in the sediments. Diatom species composition in sediments allow even further detailed reconstruction of fertility variations in the surface waters (Schuette and Schrader, 1981).

Downcore variations in species composition and abundance of diatoms and radiolaria (Fig.2e, f) indicate strong variations of fertility through time.

The oceanographic factors that control present fertility patterns are upwelling phenomena on the shelf, the Benguela Current and the prevailing wind system. The Benguela Current changes its predominantly SE-NW direction to the West in the general area where core PC 16 was retrieved; it is responsible to transport nutrient rich waters from the near shore upwelling areas offshore to the West and generates a rich and well preserved opal floral (diatoms) component in Holocene sediments. The sediments underlying with a monospecific diatom assemblage of Coscinodiscus nodulifer and reduced radiolarian contents represent times with oceanic conditions, reduced primary productivity, relatively warm waters and reduced opal flux. Infertile subtropical water masses did control sedimentation during this time. This sequence is characterized by little carbonate dissolution, which Berger (1977) attributed to decreased fertility of surface waters.

Van Zinderen-Bakker (1984) and Jansen et al. (1984) reasoned that the Benguela Current shifted its westward change to the area of the Angola Basin during the last glacial period; preventing transport of fertile waters and opaline skeletons to the area of PC 16 during the last glacial.

Diatom species indicate colder water temperatures with generally poor preservation of skeletons and low abundance during 19,000-16,000 yr B.P. Radiolaria are slightly more abundant than they are in the 13,000 15,000 yr interval. CLIMAP Project Members 


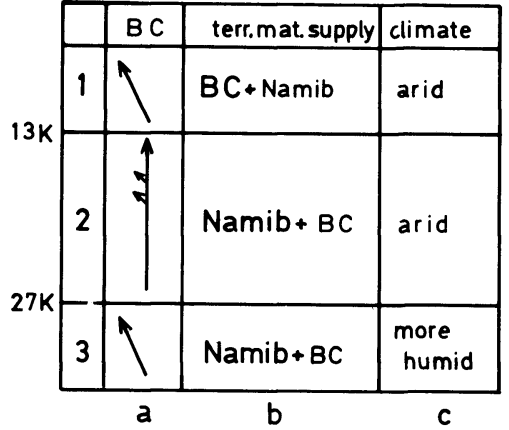

Fig.3. Summary, showing in a schematic way. a. The flow direction of the Benguela Current (BC). $\star=$ west turning in the area of PC $16 . \uparrow=\mathrm{BC}$ flows parallel to the coast to the north without turning to the west in the latitude of PC 16. b. Supply of terrigenous matter from the Namib desert (=local supply) and from the Orange River mouth area by the Benguela Current $(B C)$ (= far distant supply). c. Climate in the latitude of $24^{\circ} \mathrm{S}$ in the coastal Namib desert. Left side: $\delta^{18} \mathrm{O}$ stages $1-3$ and ages $(13,27 \mathrm{~K}=13,000$ and 27,000 yr B.P.).

(1976) have shown that during this time the main branch of the Benguela Current has changed flow pattern to the west in the Angola Basin; increased velocities might have caused a slightly increased $\mathrm{E}-\mathrm{W}$ transport of fertile waters to the area of PC 16 which is located close to the western boundary of this current.

The period from $19,000-27,000 \mathrm{yr}$ is characterized by low abundances and poor preservation of opaline microfossils. The Benguela Current has not changed its flow pattern to the west in the PC 16 area; opal supply is also reduced in stage 2 sediments retrieved from the Walvis Ridge (Diester-Haass, 1985).

Sediments older than 28,000 yr have higher opal contents and opaline skeletons are better preserved. Polar glaciers retreated during this time with generally higher temperature and possible similar flow regimes of the Benguela Current as they are today (Fig.3).

\section{Terrigenous matter and climate history}

Clay mineral analysis of samples from the Orange River, the Namib desert and from the Walvis Ridge Terrace indicated that an essential part of the terrigenous clay fraction off SW
Africa originates from the Orange River which flows into the Atlantic at $28^{\circ} \mathrm{S}$. The terrigenous matter supply from the Namib desert is minimal (Diester-Haass et al., 1986). The Orange River clay fraction is characterized by montmorillonite and illite (montmorillonite/illite ratios are greater than 1 , see Table II), whereas the Namib desert clay fraction consists primarily of illite with no montmorillonite. Sediment surface samples from the Namibian desert shelf are characterized by high proportions of illite (Bremner, 1975). Holocene sediments from core PC 16 have small amounts of coarse terrigenous material, the montmorillonite/illite ratio is $>1$ and is indicative that the local supply from the Namib desert was minimal. Present local circulation patterns also show that the eolian offshore transport is unimportant. Changes do occur at the Holocene/Pleistocene boundary with a downward increase in grain size (increase in the $6.3-20 \mu \mathrm{m}$ fraction and the $>40 \mu \mathrm{m}$ sized quartz and mica abundance), with an increase in illite and a decrease in montmorillonite (Table II). The montmorillonite/illite ratio decreases from $1.7-1.3$ to values between $0.7-1$.

We postulate an increase of Namib desert material during the last glacial; the reasons might be in an increase of wind velocities, changed predominant wind direction and/or lowering of sea-level. This Namib desert supply is superimposed upon the far distant supply from the Orange River via the Benguela Current.

No significant changes were found in sediments older than $27,000 \mathrm{yr}$; the dominance of 6.3-20 $\mu \mathrm{m}$ grain size fraction suggests a predominantly eolian transport (Sarnthein et al., 1982; Diester-Haass, 1983). The amount of the $>40 \mu \mathrm{m}$ fraction decreases slightly. Wood fibres and pellets consisting of finely dispersed terrigenous matter and wood fibres are present.

Investigations in the Namib desert carried out on cave sinter sequences (Rössing and Tinkas caves) point to wetter conditions in the period 49,000 to $34,000-33,000$ yr B.P. (Heine and Geyh, 1983; Heine, 1987) and to 
alternating arid/windy and moist periods between 33,000 and 28,000 yr B.P. (Vogel, 1982; Heine, 1985). Vogel (1982) describes vegetation in the area south of the Kuiseb River: calcareous root-casts, ${ }^{14} \mathrm{C}$ age about $37,500 \mathrm{yr}$, calcified reed casts with ${ }^{14} \mathrm{C}$ age of 30,700 and $37,000 \mathrm{yr}$. The clustering of radiocarbon dates on carbonate from the Namib desert in periods $35,000-20,000$ and $14,000-10,000$ yr B.P. suggests an increase in precipitation during those times (Teller and Lancaster, 1986). The presence of wood fibres in the marine sediments deposited prior to about $27,000 \mathrm{yr}$ may be the consequence of wetter conditions in the Namib at $22-24^{\circ} \mathrm{S}$, favoring a denser-vegetation even near the present-day hyper-arid coastal areas. We are unable to separate eolian and/or fluviatile transport. The grain size composition of the terrigenous matter might be in favor of eolian supply. Eolian transport from the Namib by northeasterly to easterly winds is corroborated by wind erosion forms described by Sweeting and Lancaster (1982) and by ventifacts (Selby, 1977; Besler, 1980). The orientation of the sandblast features indicate formation by winds from NNE to E (Fig.4). Analysis of winds recorded at the Desert Ecological Research Station (Gobabeb) shows a bidirectional wind regime with winds blowing from NNW to $\mathrm{N}$, and from $\mathrm{S}$ to $\mathrm{SW}$. Winds from NNE to $\mathrm{E}$ are less common and blow for only $8 \%$ of the time, mainly in the winter months April to August; however, during this period they account for $16 \%$ of all winds blowing at velocities above the threshold for sand movement ( $16 \mathrm{~km} / \mathrm{h})$; winds from the NNE to $\mathrm{E}$ sector account for $76 \%$ of winds at $31 \mathrm{~km} / \mathrm{h}$ and no less than $89 \%$ of all winds with velocities over $41 \mathrm{~km} / \mathrm{h}$ (Sweeting and Lancaster, 1982). Until now there do not exist models of palaeowinds over the central Namib desert and the adjacent Benguela Current during the Upper Pleistocene. A circulation model, proposed to explain present-day extended wet and dry spells (Tyson, 1986), may have palaeoclimatic implications for southern Africa, although the present-day dry-spell analogue fails to explain Benguela sea-surface

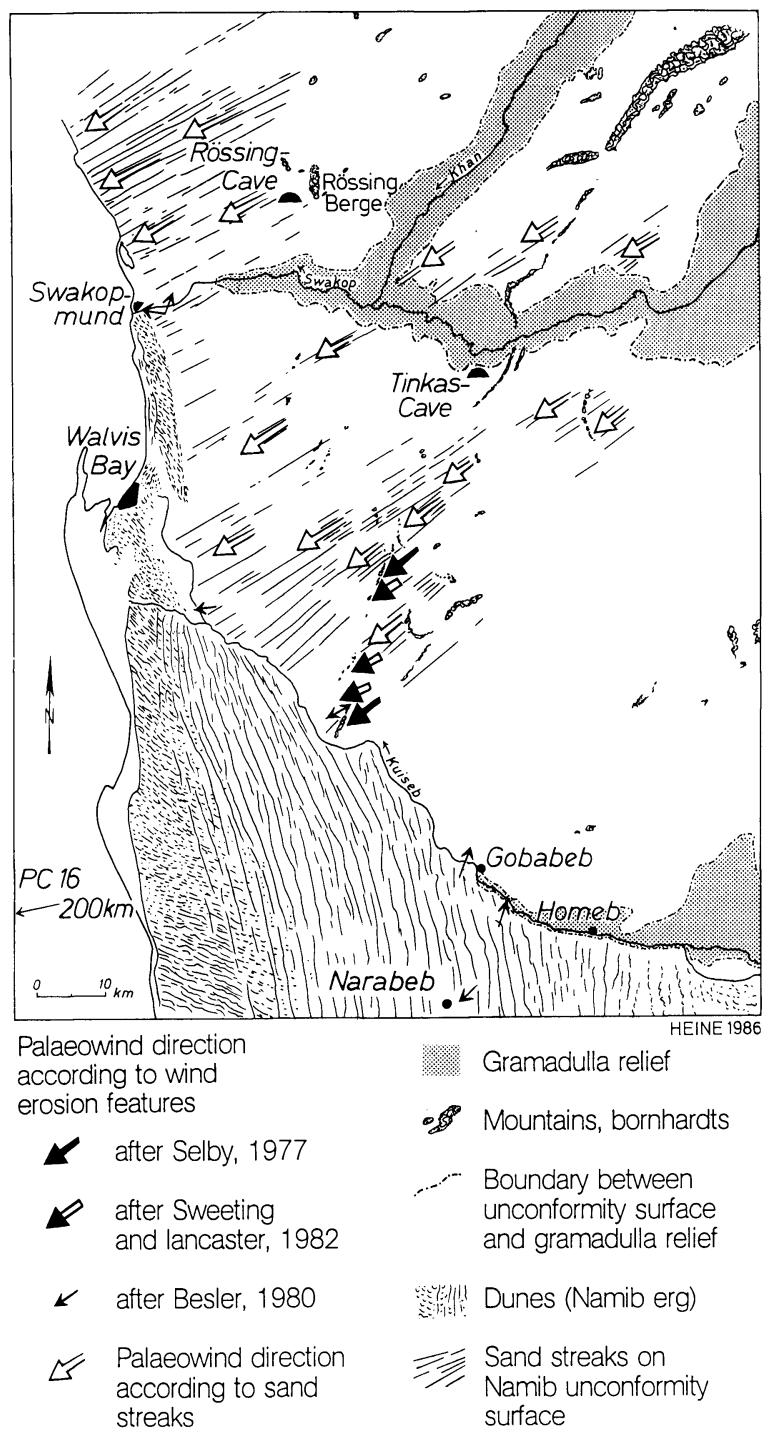

Fig.4. Wind erosion features in the central Namib desert.

temperatures at 18,000 yr B.P. (Tyson, 1986). Heine and Geyh (1983) describe alternating wet and arid/windy periods in the 33,000 28,000 yr interval. During the late stage 3 the unique climatic changes between wetter intervals and short periods with strong wind regimes may be interpreted as transition following expanding ice sheets from the marked circulation asymmetry between the northern and southern hemispheres of stage 3 interstadial to the Last Glacial Maximum with 
substantial hemispheric steepening of the meridional temperature gradient and the equatorward expansion of the circumpolar westerlies.

A river supply of the plant material would require higher percentages of $<2 \mu$ m fraction compared to the silt fraction (Sarnthein et al., 1982; Diester-Haass, 1983). Furthermore, fluviatile diatoms have not been found; diatoms of freshwater species are described from lacustrine sandy sediments at Narabeb within the northern Namib sand sea (Teller and Lancaster, 1986). During the Late Quaternary, between the bordering rivers, Kuiseb to the north and Koichab to the south, in the Namib dune field five great river systems have been active but they did not cut across the Namib Erg to the Atlantic Ocean (Besler, 1980). In case that river material was transported to the Atlantic Ocean by the Kuiseb and Swakop it was carried by the Benguela Current to the north and thus was not transported to the continental slope where core PC 16 has been taken. A supply of wood fibres from the Orange River is unlikely because of the size of wood fragments.

Several cores from the Walvis Ridge Terrace, $1300 \mathrm{~m}$ waterdepth, and equidistant from shore than PC 16 (see Fig.1 for position) are barren of plant material (Diester-Haass, 1985), an observation, that might suggest a climatic boundary between 20 and $24^{\circ} \mathrm{S}$ in the period prior to 27,000 yr B.P., with moister conditions and periodically strong NNE-E palaeowind directions in the central Namib desert and arid conditions in the northern Namib desert. During the Last Glacial Maximum (stage 2) a climatic boundary separated the central Namib with arid conditions and frequent strong NNE-E palaeowinds resulting from the occurrence of coastal lows and berg winds, from a more humid area south of about $26^{\circ} \mathrm{S}$. There is much evidence that the winter rainfall could not have extended appreciably further northward than this boundary in about $26^{\circ} \mathrm{S}$ in Last Glacial Maximum (stage 2) times (Van Zinderen Bakker, 1984).

\section{Conclusions}

(1) The Benguela Current turned west around latitude $24^{\circ}$ during oxygen isotope stages 1 and 3 and transported fertile surface water and/or diatom biocoenoses from the near shore upwelling environment offshore, producing opal rich sediments offshore. Opal content of sediments is much reduced during stage 2 because of a northward shift of the Benguela Current deflection into the Angola Basin area.

(2) Terrigenous matter originates from a local source, the Namib desert, and from a distant source, the Orange River. The local source is characterized by greater grain size and by higher illite contents. The Holocene montmorillonite/illite ratios are 1.3-1.7, and the coarse terrigenous matter is rare: an indication of a far distant source. During stages 2 and 3 an increase of the local supply was observed with an increase of grain size and a decrease of the montmorillonite/illite ratio.

(3) The occurrence of wood fibres in sediments older than $27,000 \mathrm{yr}$ suggests a more humid climate with a denser vegetation, which is in agreement with other studies done in the Namib desert. Transport mechanisms of these plant fragments is obscured and can be either eolian or fluviatile or both.

\section{Acknowledgements}

Samples of core PC 16 from Chain Cruise 115 have been provided by the Woods Hole Oceanographic Institution with funding from the National Science Foundation. We thank C. Summerhayes ar B. Bornhold for discussions and for providing unpublished information. H. Lange did the grain size analysis. Technical assistance of $M$. Killinger and E. Hartmann (Mannheim) is gratefully acknowledged. Funding was provided by the Deutsche Forschungsgemeinschaft (L. D.-H., P. R., K. H.) and the National Science Foundation (H. S.). 


\section{References}

Arrhenius, G., 1952. Sediment cores from the East Pacific. In: Report of the Swedish Deep-Sea Expedition 1947-1948, 5: 1-228.

Berger, W. H., 1976. Biogenous deep-sea sediments: production, preservation and interpretation. In: J. P. Riley and R. Chester (Editors), Chemical Oceanography, 5. Academic Press, London, 2nd ed., pp. 265-388.

Berger, W. H., 1977. Deep-sea carbonate and the deglaciation preservation spike in pteropods and foraminifera. Nature, 269: 301-303.

Besler, H., 1980. Die Dünen-Namib. Entstehung und Dynamik eines Ergs. Stuttg. Geogr. Stud., 96, 208 pp.

Bremner, J. M., 1975. Mineralogy and distribution of clay minerals on the South-West African continental shelf and adjacent hinterland. Geol. Dep. Univ. Cape Town, Tech. Rep., 7: 46-55.

Broecker, W. S., 1971. Calcite accumulation rates and glacial to interglacial changes in oceanic mixing. In: K. K. Turekian (Editor), Late Cenozoic Glacial Ages. Yale Univ. Press, London, pp. 239-265.

CLIMAP Project Members, 1976. The surface of the ice-age earth. Science, 191: 1131-1144.

Darbyshire, M., 1966. The Benguela Current. In: R.W. Fairbridge (Editor), Encyclopedia of Oceanography. Dowden, Hutchinson and Ross, Stroudsburg, Pa., pp. $123-128$.

Diester-Haass, L., 1983. Differentiation of high oceanic fertility in marine sediments caused by coastal upwelling and/or river discharge off Northwest Africa during the Late Quaternary. In: J. Thiede and E. Suess (Editors), Coastal Upwelling. Its Sediment Record. (NATO Conf. Ser., IV, 10b), Plenum Press, New York, N.Y., pp. 399-419.

Diester-Haass, L., 1985. Late Quaternary sedimentation on the Eastern Walvis Ridge, SE Atlantic (HPC 532, Leg 75 and four piston cores). Mar. Geol., 65: 145-189.

Diester-Haass, L., Schrader, H.-J. and Thiede, J., 1973. Sedimentological nd paleoclimatological investigations of two pelagic ooze cores off Cape Barbas, North-West Africa. Meteor Forsch. Ergeb., C, 16: 19-66.

Diester-Haass, L., Meyers, P. A. and Rothe, P., 1986. Light-dark cycles in opal-rich sediments near the PlioPleistocene boundary, DSDP Site 532, Walvis Ridge Continental Terrace. Mar. Geol., 73: 1-23.

Embley, R. W. and Morley, J. J., 1980. Quaternary sedimentation and paleoenvironmental studies off Namibia (South-West Africa). Mar. Geol., 36: 183-204.

Goll, R. M. and Bjorklund, K. R., 1974. Radiolaria in surface sediments of the South Atlantic. Micropaleontology, 20(1): 38-75.

Hagen, E., Schemainda, R., Michelsen, N., Postel, L., Schulz, S. and Below, M., 1981. Zur küstensenkrechten Struktur des Kaltwasserauftriebes vor der Küste Namibias. Geod. Geophys. Veröff. Reihe, IV, 36, 99 pp.

Hart, T. J. and Currie, R. T., 1960. The Benguela Current. Discovery Rep., 31: 123-298.

Heine, K., 1985. Late Quaternary development of the Kuiseb River Valley and adjacent areas, central Namib desert, South West Africa/Namibia, and paleoclimatic implications. Z. Gletscherkd. Glazialgeol., 21: 151-157.

Heine, K., 1987. Jungquartäre fluviale Geomorphodynamik in der zentralen Namib, Südwestafrika/Namibia. Z. Geomorphol., N.S., 66: 113-134.

Heine, K. and Geyh, M. A., 1983. Radiocarbon dating of speleothems from the Rössing cave, Namib desert, and paleoclimatic implications. In: J. C. Vogel (Editor), Late Cenozoic Paleoclimates of the Southern Hemisphere. Balkema, Rotterdam, pp. 465-469.

Jansen, J. H. F., Van Weering, T. C. E., Gieles, R. and Van Iperen, J., 1984. Middle and Late Quaternary oceanography and climatology of the Zaire-Congo fan and adjacent eastern Angola Basin. Neth. J. Sea Res., 17(2-4): 201-249.

Johnson, T. C., 1974. The dissolution of siliceous microfossils in surface sediments of the eastern tropical Pacific. Deep-Sea Res., 21: 851-864.

Martin, R. A., 1981. Benthonic foraminifera from the Orange-Lüderitz shelf, southern African continental margin. Bull. Mar. Geosci. Unit, II, Dep. Geol., Univ. Cape Town, 82 pp.

Müller, G. and Gastner, M., 1971. The "Karbonat-Bombe", a simple device for the determination of the carbonate content in sediments, soils and other materials. Neues Jahrb. Miner. Monatsh., 10: 466-469.

Sarnthein, M., 1971. Oberflächensedimente im Persischen Golf und Golf von Oman, II. Quantitative Komponentenanalyse der Grobfraktion. Meteor Forsch. Ergeb., C, 5: $1-113$.

Sarnthein, M., Thiede, J., Pflaumann, U., Erlenkeuser, H., Fütterer, D., Koopmann, B., Lange, H. and Seibold, E., 1982. Atmospheric and oceanic circulation patterns off NW Africa during the past 25 Mill. years. In: U. von Rad, K. Hinz, M. Sarnthein and E. Seibold (Editors), Geology of the Northwest African Continental Margin. Springer, Berlin, pp. 545-604.

Schrader, H. and Gersonde, R., 1978. Diatoms and silicoflagellates in the eight meters section of the lower Pliocene of Capo Rosselo. Utrecht Micropaleontol. Bull., 17: 129-176.

Schuette, G. and Schrader, H.-J., 1981. Diatom taphocoenoses in the coastal upwelling area off South West Africa. Mar. Micropaleontol., 6: 131-155.

Selby, M. J., 1977. Palaeowind directions in the central Namib desert as indicated by ventifacts. Madoqua, 10: 195-198.

Simpson, E. S., 1971. The Geology of the south-west African continental margin: a review. In: The geology of the east-Atlantic continental margin. ICSU/SCOR Working Party, 31, Symp. Cambridge, 1970. Inst. Geol. Sci., London, Rep. No. 70/16, pp. 153-170.

Summerhayes, C. P., 1983. Sedimentation of organic matter in upwelling regimes. In: J. Thiede and E. Suess (Editors), Coastal Upwelling. Its Sediment Record. (NATO Conf. Ser., IV, 10b.) Plenum Press, New York, N.Y., pp. 29-72.

Summerhayes, C. P., Bornhold, B. D. and Embley, R. W., 1979. Surficial slides and slumps on the continental slope and rise of south-west Africa: a reconnaissance study. Mar. Geol., 31: 265-277. 
Sweeting, M. M. and Lancaster, N., 1982. Solutional and wind erosion forms on limestone in the Central Namib Desert. Z. Geomorphol. N. F., 26: 197-207.

Teller, J. T. and Lancaster, N., 1986. Lacustrine sediments at Narabeb in the central Namib desert. Palaeogeogr., Palaeoclimatol., Palaeoecol., 56: 177-195.

Thiede, J., Suess, E. and Müller, P. J., 1982. Late Quaternary fluxes of major sediment components to the sea floor at the North-West African continental slope. In: U. von Rad, K. Hinz, M. Sarnthein and E. Seibold (Editors), Geology of the North-West African continental margin. Springer, Berlin, pp. 605-631.
Thunell, R. C., 1976. Calcium carbonate dissolution history in Late Quaternary deep-sea sediments, western Gulf of Mexiko. Quat. Res., 6: 281-297.

Tyson, P. D., 1986. Climatic Change and Variability in Southern Africa. Oxford Univ. Press, Cape Town, $220 \mathrm{pp}$.

Van Zinderen Bakker, E. M., 1984. Aridity along the Namibian coast. In: Paleoecology of Africa, 16. Balkema, Cape Town, pp. 149-160.

Vogel, J. C., 1982. The age of the Kuiseb river silt terrace at Homab. In: Paleoecology of Africa, 15. Balkema, Cape Town, pp. 201-209. 